\title{
The PLANTCULT Project: identifying the plant food cultures of ancient Europe
}

\author{
Soultana-Maria Valamoti ${ }^{1, *}$, Stefanie Jacomet ${ }^{2}$, Hans-Peter Stika ${ }^{3}$ \\ $\&$ Andreas G. Heiss ${ }^{4}$
}

Plant foods are closely connected to cultural, social and economic aspects of human societies, both past and present. Food-preparation techniques and the etiquette of consumption involve complex interactions of natural resources and human cultures. During European prehistory, these changes included the shift to sedentism, the cultivation and domestication of plants, food storage, the production and exchange of alcoholic beverages and luxury foodstuffs, and the continuous adaptation of established culinary practices to newcomers in fields and gardens.

The ERC-funded PLANTCULT Project explores the role of the culinary transformation of plant ingredients in the shaping of social and cultural identities during prehistory, and the contribution of plant foods to social cohesion and differentiation, including the emergence of elites, in daily, communal or special consumption contexts. Our aim is to identify culinary cultures and their transformation over time across a large region, stretching from the Aegean to Central Europe, and focusing on several key sites rich in the remains of plant foods such as bread, beer, oil and wine (Figure 1). Each part of this region presents a different trajectory of social development under influences from the Eastern Mediterranean and Central Asia. We wish to understand the role of culinary practice and innovation in shaping these trajectories; the chosen study area allows us to explore an east-west dynamic at a wide geographic scale.

\section{An integrated methodology}

The project adopts an integrated approach that combines plant food remains, processing equipment, ancient written sources, experimental archaeology and ethnography (Figure 2). The remains of food plants, however, form the focus of our investigation. Ancient samples from key sites are being studied in detail and will involve the development of new

1 School of History and Archaeology, Department of Archaeology, Aristotle University of Thessaloniki (AUTH), 54124 Thessaloniki, Greece

2 Integrative Prehistory and Archaeological Science (IPAS), Department of Environmental Sciences, University of Basel, Spalenring 145, CH-4055 Basel, Switzerland

3 Institute of Botany, University of Hohenheim (UHOH), D-70593 Stuttgart, Germany

4 Austrian Archaeological Institute (ÖAI), Austrian Academy of Sciences (ÖAW), Franz Klein-Gasse 1, 1190 Vienna, Austria

* Author for correspondence (Email: sval@hist.auth.gr)

(C) Antiquity Publications Ltd, 2017 ANTIQUITY 91 358, e9 (2017): 1-7 


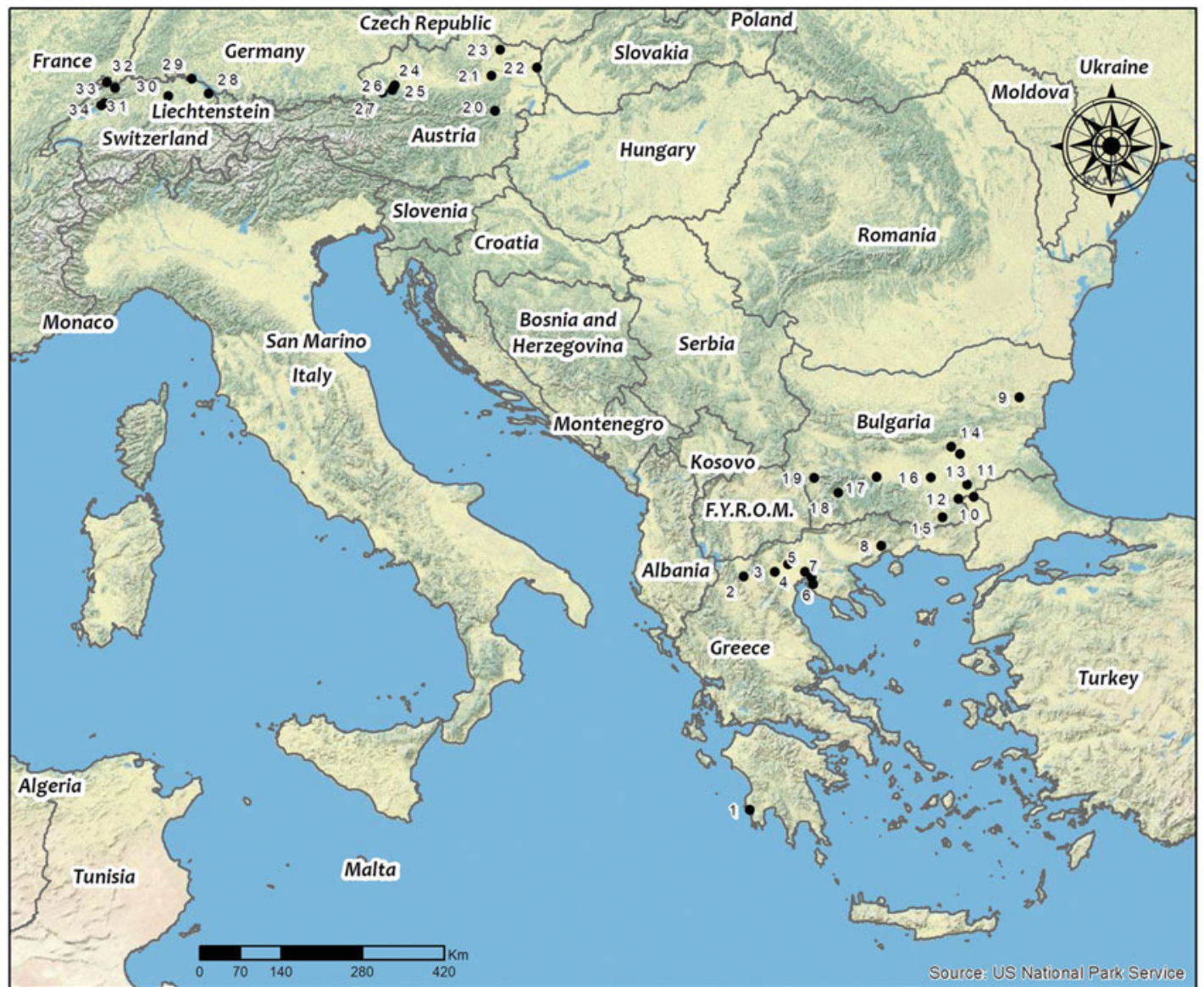

Figure 1. Study area with key sites. 1) P.O.T.A. Romanou; 2) Limnochori; 3) Angelochorio; 4) Archontiko; 5) Agios Athanasios; 6) Karaburnaki; 7) Mesimeriani Toumba; 8) Dikili Tash; 9) Provadia; 10) Kapitan Andreevo; 11) Vaskovo; 12) Kush Kaya; 13) Sokol; 14) Karanovo; 15) Ada Tepe; 16) Yabalkovo; 17) Kapitan Dimitrievo; 18) Bresto; 19) Mursalevo; 20) Prigglitz-Gasteil; 21) Haselbach 'Im äußeren Urban'; 22) Stillfried an der March 'In der Gans'; 23) Roseldorf Sandberg; 24) Seewalchen Sprungturmgrube; 25) Weyregg II; 26) Lenzing; 27) Mondsee Station See; 28) Arbon Bleiche 3; 29) Hornstaad-Hörnle IA; 30) Zurich-Parkhaus Opéra; 31) Delemont/En la Pran; 32) Alle/Les Aiges; 33) Twann; 34) Thunstetten. 


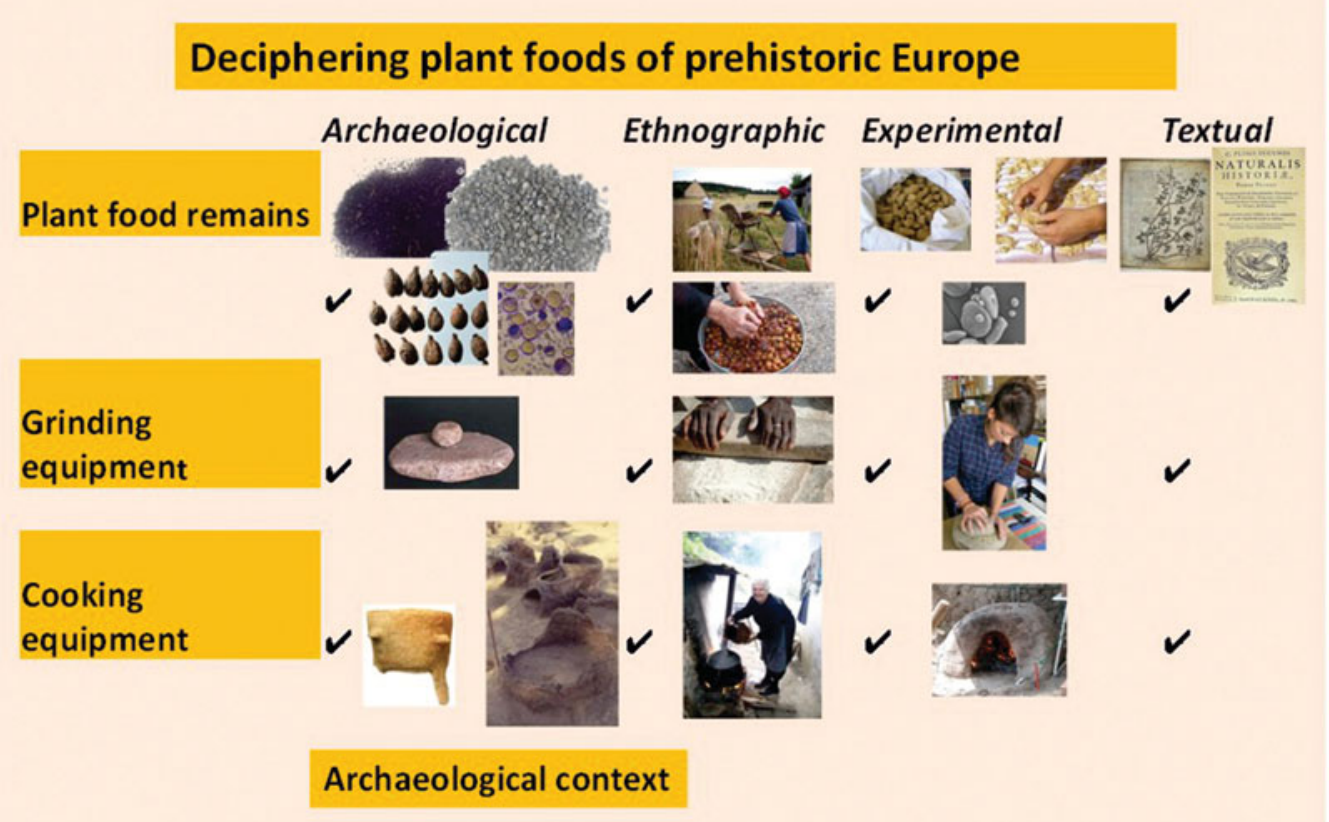

Plant food data base

Figure 2. The PLANTCULT Project: an integrated research model.

methodological tools. To this end, a significant body of material (Figure 3) will be examined by stereomicroscopy and scanning electron microscopy (SEM), and will be interpreted by comparison with experimentally generated samples. The latter will be created using observations based on archaeological materials, ethnographic records and ancient texts. For example, pilot investigations have explored the effects of food processing, such as grinding and boiling, on grain morphology (fracture surfaces and endosperm structure, e.g. Valamoti 2002, 2011; Valamoti et al. 2007, 2011). Analyses of the components and production traits of ancient finds of bread (Heiss et al. 2015), grape juice extraction and fermentation (Valamoti et al. 2007; Garnier \& Valamoti 2016) and beer-making (Stika 2011) demonstrate the need to develop new methodological tools for the effective analysis of archaeobotanical samples. The project will explore microscopic structures (Figure 3e-f) both in the ancient and the modern experimental samples, which will allow for the proper identification of different plant foods in the archaeobotanical record. We will record which plants were used as foods and the ways that they were transformed into meals, and we will explore why specific food choices, both staples and special food substances, such as alcohol and oil, changed over time and what their links were to emerging social hierarchy.

As the type and scale of food-preparation equipment are closely linked to culinary practice and socio-economic identities, we will address variability and change in 


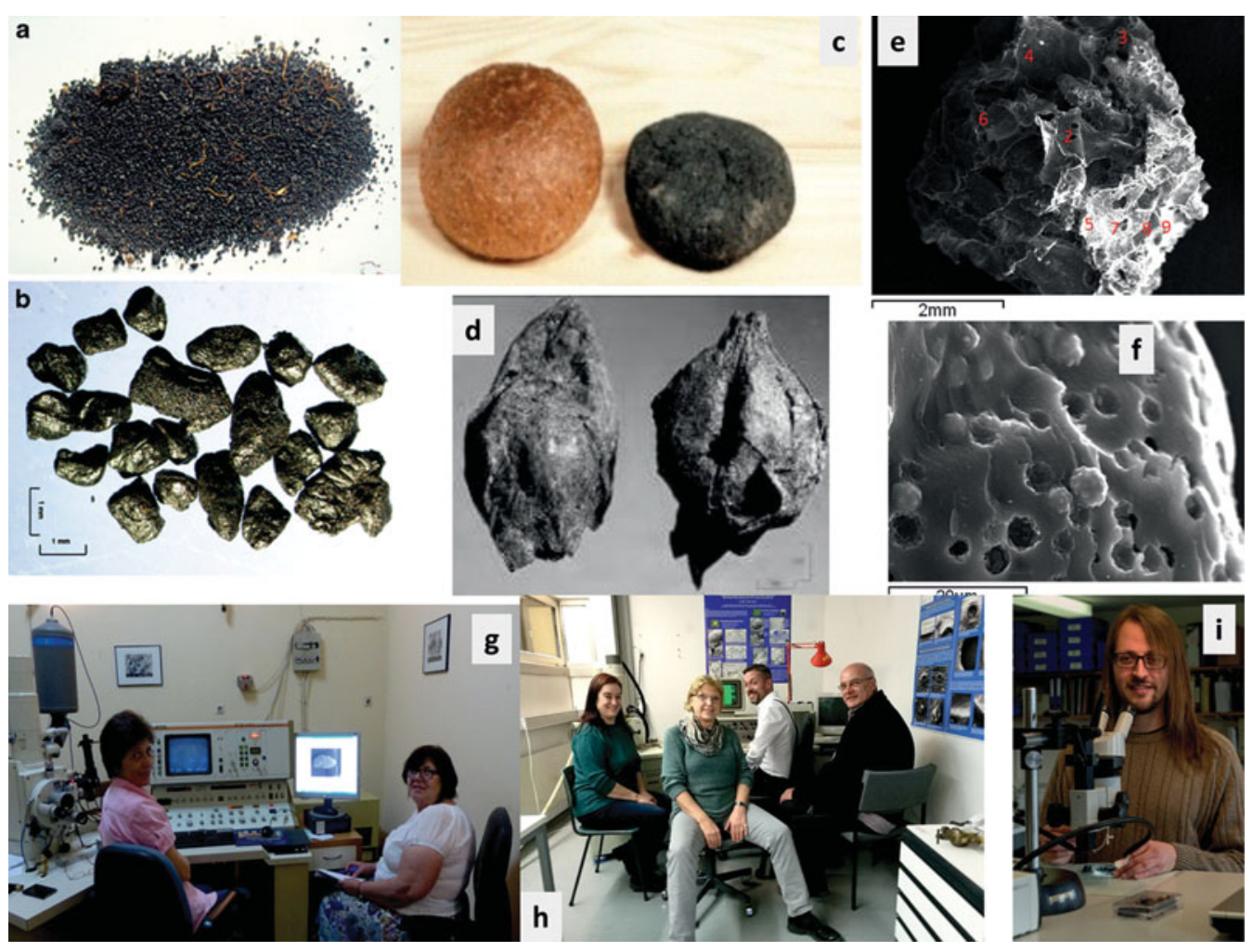

Figure 3. Examples of ancient plant foods that will be studied by SEM. Greece: a) ground wheat 'bulgur' (Mesimeriani Toumba); b) detail of a; Switzerland: c) bread (Twann, 329_1981_82_400_2.jpg, (C) Archäologischer Dienst Bern); d) grape pressings (Dikili Tash); e-f) Bulgaria: 'food' fragments from Kush Kaya (Popov et al. in press); g) SEM work at Aristotle University of Thessaloniki (L. Papadopoulou, Tz. Popova); h) University of Hohenheim (S.M.V., A.G.H., H.-P. S.); i) University of Basel (F. Antolin).

food-preparation technologies by assembling information on stone grinding tools, cooking facilities and pottery, and the plant macro- and micro-remains trapped within them. Associations between cooking, food sharing and alleged household individualisation processes (cf. Halstead 1999) will thus be explored. A database of plant food ingredients (Kreuz \& Schäfer 2002), plant foods (ancient and experimental), equipment and archaeological contexts will form the basis for mapping culinary signatures across the study area.

\section{Samples of ongoing work}

\section{Archaeobotany and grinding technology (Figure 4)}

We will use experimental and ethnographic information to explore the association between plant ingredients, the raw materials used for tools and grinding productivity. The resulting use-wear traces and plant micro-remains will be employed as a middle-range device to explore archaeological finds. They will also form a reference database.

(C) Antiquity Publications Ltd, 2017 

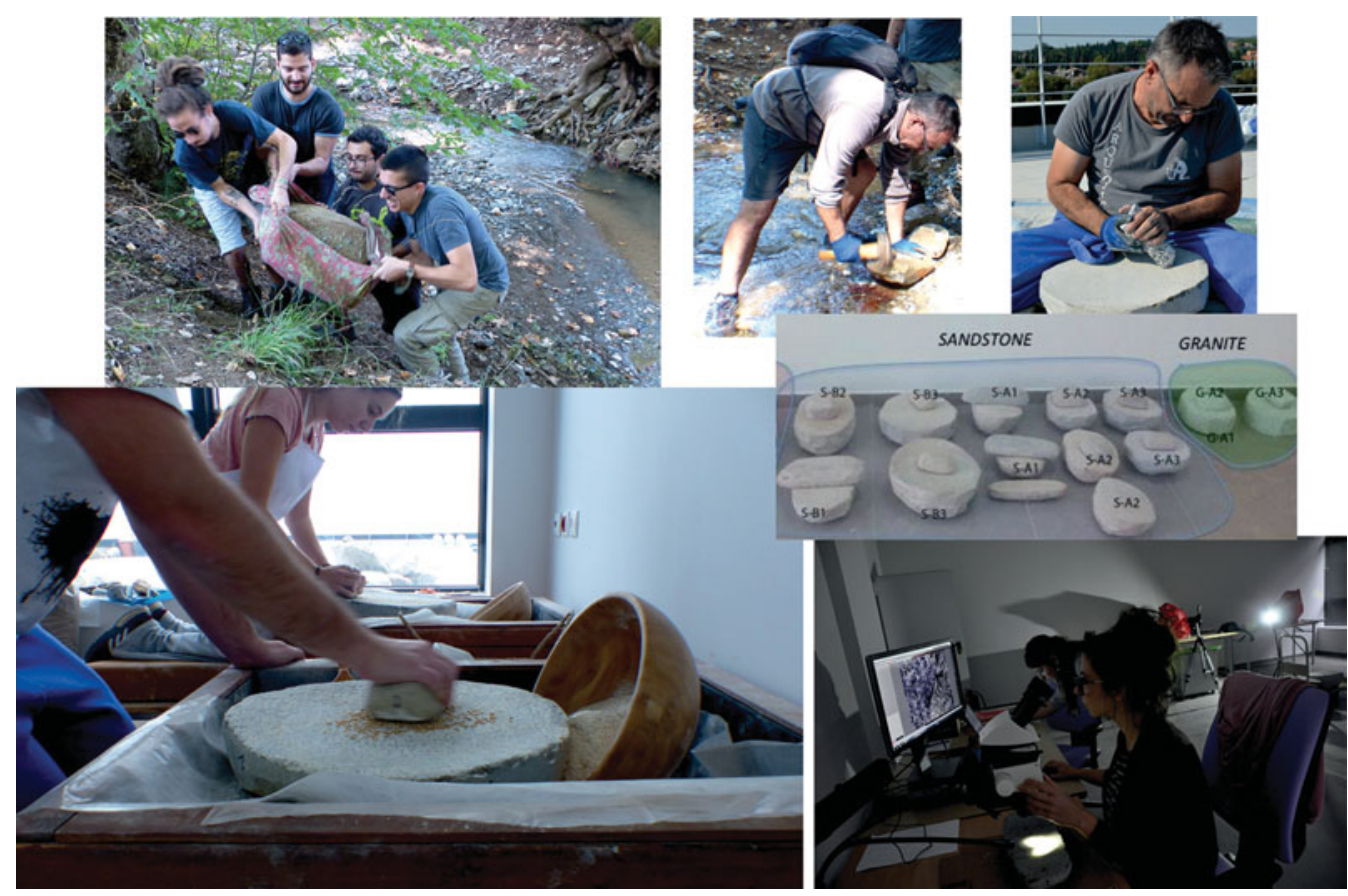

Figure 4. Procurement (T. Dimoudis, N. Kardakos) and manufacture (A. Palomo) of grinding tools for experiments (P. Lathiras, E. Almasidou). Studying use-wear of experimental grinding stones at PLANTCULT headquarters, KEDEK (Centre for Interdisciplinary Research and Innovation, AUTH) (M. Bofill \& D. Chondrou).
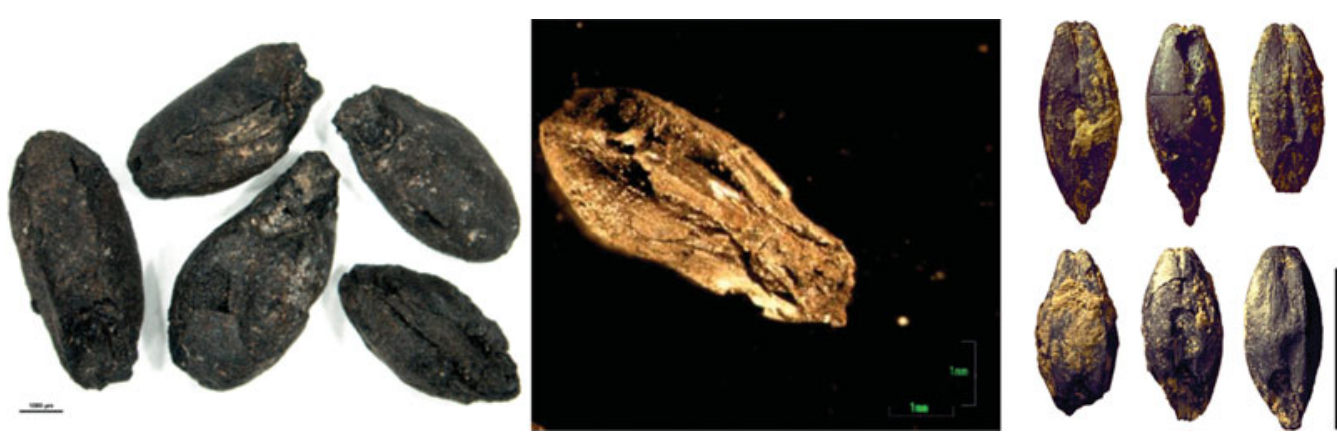

Figure 5. Sprouted barley grains from Bronze Age Argissa Magoula (2100-1700 BC, photographs Lower Saxony Institute for Historical Coastal Research, Wilhelmshaven), Archondiko Giannitson (2100-1700 BC) in Greece, and Hochdorf in Germany, fourth century BC (Stika 2011).

\section{The interface between beer and wine cultures (Figure 5)}

By using archaeobotanical and textual evidence, together with residue analyses, we are exploring beer- and wine-making. The interface between wine and beer cultures will be explored on a wide regional scale; for example, the Mediterranean vs Central Europe. But we will also explore this interface at a regional scale. Taking Greece as a case study, our initial research reveals that assumptions about wine-making and -consumption over the

(C) Antiquity Publications Ltd, 2017 




Figure 6. Collecting modern ethnographic data (clockwise from top left): acorn harvesting at Grevena; winnowing grasspea on Corfu; making grape syrup at Grevena; making Grünkern (green-harvested and roasted/smoked spelt), recorded by Marian Berihuete Azorin; S.M. Valamoti roasting acorns for experimental foods.

longue durée may be wrong, as archaeobotanical finds indicate Bronze Age beer-making in Greece.

\section{Plant foods from prehistory to the present (Figure 6)}

The project is also undertaking ethnographic work on specific plant foods that were probably used in the past; for example, split pulses, Grünkern (green-harvested and roasted/smoked spelt) and wine and grape syrup. This will not only inform our archaeological inquiries, but also open the way towards connecting our research with contemporary society and small companies in the food sector.

The PLANTCULT Project started in April 2016 and is hosted by Aristotle University with three partner institutions: the University of Basel, the University of Hohenheim and the Austrian Academy of Sciences. Our research will allow us to explore how the powerful sensory experience of food preparation and consumption transformed nature into culture, shaped collective memory and identity, and contributed to the emergence of hierarchical societies across large parts of Europe. In this way, we aim to contribute towards the growing awareness of Europe's culinary heritage.

(C) Antiquity Publications Ltd, 2017 


\section{The PLANTCULT team}

The project consists of 47 members (including the principal investigator, S.M.V. and partners S.J., H.-P.S. and A.G.H.). The project postdoctoral researchers are: F. Antolin (University of Basel), M. Bofill, A. Bourliva, M. Berihuete-Azorín (University of Hohenheim), A. Dimoula, I. Hristova, E. Kalogiropoulou, S. Laparidou, M. Ntinou, C. Pagnoux and A. Palomo. The project PhD students are: A. Anagnostoudis, T. Bekiaris, D. Chondrou, S. Michou, D. Nenova, I. Ninou, C. Petridou, G. Prats, Th. Roustanis, K. Symponis, N. Vouronikou, P. Tokmakides and A. Tzelepidou, all based at Aristotle University of Thessaloniki unless otherwise indicated. Project team members contributing specialist advice and material are: N. Alonso, A. Bakalaki, L. Bouby, O. Craig, G. Fiorentino, V. Fyntikoglou, M. Ivanova, A. Kreuz, E. Marinova, C. McNamee, P. Nigdelis, V. Zech-Matterne, L. Papadopoulou, K. Pavlidis, Tz. Popova, S. Prevost-Dermarkar, E. Papadopoulou, M. Primavera, H. Procopiou, J.F. Terral, K. Tokmakides, G. Tsartsidou, Z. Tsirtsoni and S. Vergopoulos.

Further details on the project are available at http://plantcult.web.auth.gr/index.php/en/

\section{Acknowledgements}

This project has received funding from the European Research Council under the European Union's Horizon 2020 research and innovation programme (grant agreement 682529, consolidator grant 2016-2021). The article reflects only the authors' views.

\section{References}

Garnier, N. \& S.M. Valamoti. 2016. Prehistoric wine-making at Dikili Tash (northern Greece): integrating residue analysis and archaeobotany. Journal of Archaeological Science 74: 195-206. https://doi.org/10.1016/j.jas.2016.03.003

Halstead, P. 1999. Neighbours from hell? The household in Neolithic Greece, in P. Halstead (ed.) Neolithic society in Greece: 77-95. Sheffield: Academic.

Heiss, A.G., N. Pouget, J. Wiethold, A. Delor-Ahü \& I. Le Goff. 2015. Tissue-based analysis of a charred flat bread (galette) from a Roman cemetery at Saint-Memmie (Dép. Marne, Champagne-Ardenne, north-eastern France). Journal of Archaeological Science 55: 71-82. https://doi.org/10.1016/j.jas.2014.12.014

Kreuz, A. \& E. Schäfer. 2002. A new archaeobotanical database programme. Vegetation History and Archaeobotany 11: 177-79. https://doi.org/10.1007/s003340200019

Popov, H., E. Marinova, I. Hristova \& S. Iliev. In press. Plant food from the Late Bronze and Iron Age hilltop site Kush Kaya, Eastern Rhodope Mountains, Bulgaria: insights on the cooking practices, in M. Ivanova, P. Stockhammer, B. Athanassov, V. Petrova \& D. Takorova (ed.) Social dimensions of food in the prehistory of Eastern Balkans and neighbouring areas. International Academy conference, Heidelberg, 30 April-2 May 2015.
Stika, H.-P. 2011. Early Iron Age and late medieval malt finds from Germany: attempts at reconstruction of early Celtic brewing and the taste of Celtic beer. Archaeological and Anthropological Sciences 3: 41-48. https://doi.org/10.1007/s12520-010-0049-5

Valamoti, S.M. 2002. Food remains from Bronze Age Archondiko and Mesimeriani Toumba in northern Greece? Vegetation History and Archaeobotany 11: 17-22. https://doi.org/10.1007/s003340200002

- 2011. Ground cereal food preparations from Greece: the prehistory and modern survival of traditional Mediterranean 'fast foods'. Archaeological and Anthropological Sciences 3: 19-39. https://doi.org/10.1007/s12520-011-0058-z

Valamoti, S.M., M. Mangafa, C. Koukouli-Chrysanthaki \& D. Malamidou. 2007. Grape-pressings from northern Greece: the earliest wine in the Aegean? Antiquity 81: 54-61. https://doi.org/10.1017/S0003598X00094837

Valamoti, S.M., A. Moniaki \& A. Karathanou. 2011. An investigation of processing and consumption of pulses among prehistoric societies: archaeobotanical, experimental and ethnographic evidence from Greece. Vegetation History and Archaeobotany 20: 381-96. https://doi.org/10.1007/s00334-011-0302-6

(C) Antiquity Publications Ltd, 2017 